\title{
Metopism in Adult Skulls from Southern Brazil
}

\author{
Metopismo en Cráneos del Sur de Brasil \\ *Marco Antonio Sant'Ana Castilho; **Juliano Yasuo Oda; ***'Débora de Mello Gonçales Sant'Ana
}

CASTILHO, S. M. A.; ODA, Y. J. \& SANTÁNA, G. D. M. Metopism in adult skulls from southern Brazil. Int. J. Morphol., 24(1):6166, 2006.

SUMMARY: The metopic suture is found between the frontal bone tubers, there being divergences concerning the precise time of its closure, varying from the first to tenth year of life, and it can persist until adult age (metopism).

A study was conducted in 71 dry skulls of adult Brazilian subjects of both sexes (43 males and 28 females), with ages ranging from twenty five to eighty years from the bone collection of the Laboratory of Human Anatomy of the Paranaense University - UNIPAR, Brazil.

It was observed the occurrence of metopism in $7.04 \%(05 / 71)$ of the studied skulls, of which $80 \%(4 / 5)$ were female and only $20 \%$ (1/5) male. The incomplete metopic suture was found in $32.39 \%$ (23/71), with higher frequency in female skulls, 60.86\% (14/23), when compared to the male ones, that reached $31.13 \%$ (9/23). Sutures showed variations of morphology, the linear type being the most frequent, with 69.56\% (16/23). Different incidences of metopic suture were found in the different antrophometric types of skulls. Incomplete metopic sutures were predominant in the brachycranics, while complete metopic sutures had the same incidence in mesocranics, $40 \%$ ( $2 /$ 5) and dolichocranics, $40 \%(2 / 5)$.

KEY WORDS: Human Anatomy; Metopic suture; Metopism.

\section{INTRODUCTION}

The metopic suture is found between the tubers of the frontal bone, and undergoes intramembranous ossification from two primary centers, one from each half, that appear by the end of the second month of fetal life (Gray, 1988) and fuse first at the inner face of the skull (Moore, 1994), with the closure provided by chondroid tissue (Manzanares et al., 1988). Divergences are observed in the scientific literature concerning the exact period of the closure, with fusions being reported between the first and the early second year of life (Keith, 1948), generally before the second year of life (Chopra, 1957 apud Manzanares et al.), between the fifth and sixth year (Romanes, 1972 apud Ajmani et al., 1983), between the sixth and eighth year (Ajmani et al.) and between the sixth and the tenth year of age (Jit \& Shah, 1948 apud del Sol et al., 1989).

The period of maintenance of sutures in general has been suggested as a pre-condition for the continuous growth of the bones (Watzek et al., 1982) and as an indirect factor for the normal growth of the skull (Hinton et al., 1984 apud Manzanares et al.), because of that the early closure of the metopic suture results in cranial morbid deformities known as scaphocephaly (Plese et al.,1990; Moore). It is observed, however, that in some instances this suture persists until an advanced age, after the disappearance of other sutures (Piersol, 1916 apud Agarwal et al., 1979), this being named metopism (Madeira, 1995). Metopism is more often present in races where longilineal individuals predominate; on the other hand, it had no defined relation with brachicephaly (Bryce, 1917). The closure of the other sutures of the skull begin between 26 and 30 years of age, with subsidiary periods of activity by the age of 50 and being completely closed at the end of the seventh decade of age (Todd \& Lyon, 1924 apud Manzanares et al.).

The knowledge of the anatomy of the metopic suture is important because its permanence can be mistaken for a cranial fracture in radiological images (del Sol et al.), or

\footnotetext{
* Biologist, Technician Assistant, Laboratory of the Human Anatomy, Universidade Paranaense, Brasil.

** Prof. of Human Anatomy, Universidade Paranaense, Brasil. jyoda@unipar.br

*** Prof. of Human Anatomy, Universidade Paranaense, Brasil. debora@unipar.br
} 
even for the sagittal suture (Ajmani et al.). It is also important for paleodemography and forensic medicine (Hauser et al., 1991).

According to the studies of del Sol et al., metopism can be related to varied causes, such as: abnormal growth of the cranial bones, pathologic metopism triggered by hydrocephalus, growth interruption, heredospecific factors, sexual influence, heredity, atavism (emergence of a feature supposedly present in a remote ancestral, as a function of random recombination of genes or environmental conditions favorable to its expression in the embryo), stenocrotaphia (abnormal narrowing of the temporal area of the head), plagiocephaly (cranial malformation causing a twisted and asymmetrical head because of the synostosis of the cranial sutures), scaphocephaly (deformed head, projecting forward like the keel of a boat), mechanical causes and hormonal dysfunction. The genetic influence is currently the factor most accepted by the scientific community.

According to the classical anatomic literature, there are different incidences when ethnic groups are compared. The incidence of metopism in Alpine skulls is $63.2 \%$, the largest reported (Comas et al. apud del Sol et al.), while the smallest was described in Australian and Scottish skulls (1.0\%), (Bryce et al., 1915 apud del Sol et al.). In Brazil, according to del Sol et al., the incidence of metopism is close to the minimum world index, $2.75 \%$. Reports were not found concerning the incidence of metopism in different regions of Brazil. These data would be important in view of the large territorial dimensions of Brazil and the different populational structures present. Its colonization from different nations led to the formation of a population with unique physical features and it is believed that complementary studies are necessary to demonstrate the morphologic features of the bones of Brazilians from different regions, enlarging the literature devoted to the anatomy of our people.

The purpose of this work was to contribute to the scientific literature, providing anatomical data on the persistence and variations of the metopic suture in the adult population of Southern Brazil and its relations with the gender and the anthropometric types of skull.

\section{MATERIAL AND METHOD}

Seventy-one dry skulls from adult individuals of both sexes, being 43 male and 28 female according to the criteria of sexual dimorphism (Gray), and age range from 25 and 80 years, were studied. The skulls were from the bone collection of the Laboratory of Human Anatomy of the Paranaense University - UNIPAR. None of them showed visible abnormalities or signs of disease.
The analysis and description of the sutures were made by macroscopic observation of the skulls. Then, these skulls were divided into three initial groups for each sex: those having a complete metopic suture (Fig. 1); those with incomplete suture and those without apparent signs of the suture. The metopic sutures were considered complete when they extended from the nasion to the bregma uninterruptedly (Fig. 1) and incomplete when extending from the nasion to varied points of the frontal bone anterior to the bregma (Agarwal et al.; Ajmani et al.) (Fig. 2). The complete and incomplete sutures had their length measured with a millimetered tapeline. The shape of the complete sutures was observed and described. It was also verified the anterior and posterior ends of the suture and the existence of continuity with the internasal and sagittal sutures.

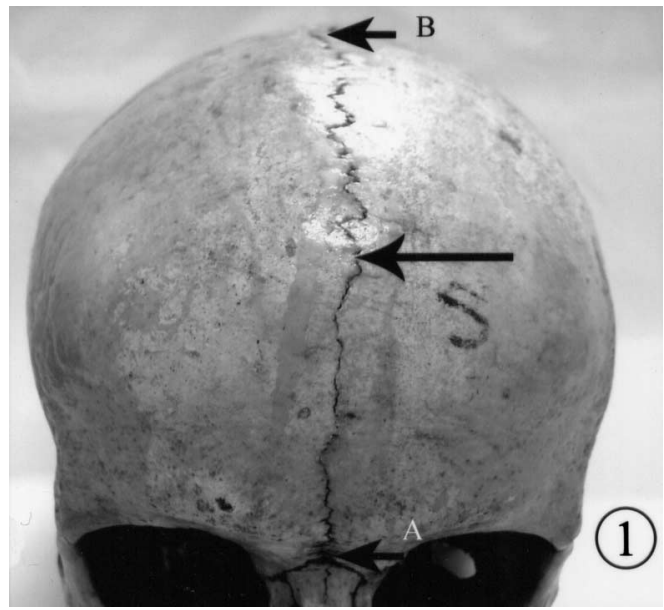

Fig. 1. Arrow indicating a complete metopic suture. The metopic suture extends from the nasion (A) to the bregma (B).

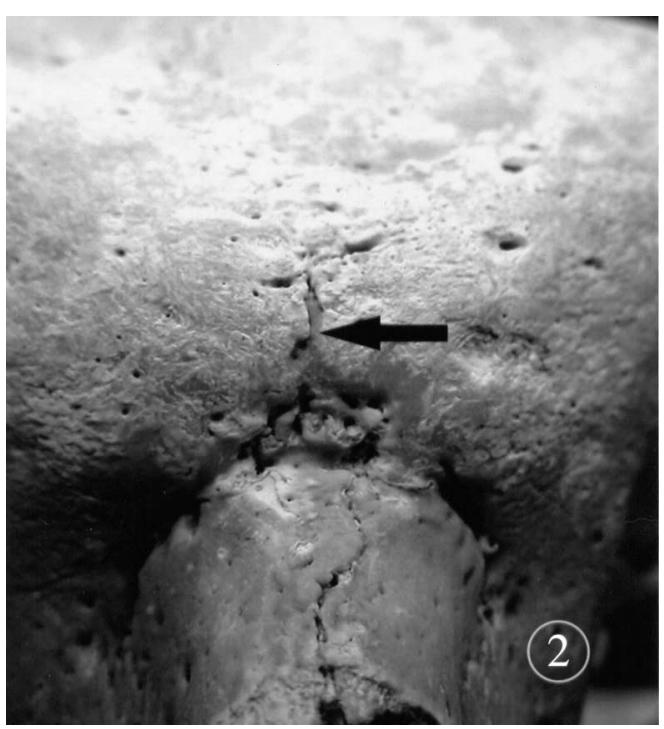

Fig. 2. Linear type of incomplete metopic suture (arrow). 
The incomplete sutures of both sexes were classified according to their morphology as: linear, those single and shallower sutures; V-shaped, those bifurcated; and double, those being independent from their origin. This classification was based on the descriptions of Agarwal et al. and Ajmani et al.

The skulls were classified according to their anthropometric characteristics using the criteria of cranial indices put forward by Gray. The male and female skulls were further divided into brachicranic, mesocranic and dolichocranic and the previous classifications were correlated with these anthropometric types.

All the measures were obtained by the same investigator and represent the simple arithmetic means of three repetitions for each parameter analyzed. The data obtained were tabulated and analyzed through descriptive statistics.

\section{RESULTS}

The incidence of metopism (Fig. 1) was observed in $7 \%(5 / 71)$ of the skulls studied, being $80 \%$ (4/5) female and $20 \%(1 / 5)$ male. On the other hand, the incomplete metopic suture was found in $32.4 \%$ of the skulls (23/71), being more frequent in females $(64.28 \%, 14 / 23)$ than in males $(39.1 \%$, $9 / 23$ ). In $60.6 \%$ (43/71) of the skulls studied vestiges of the metopic suture were not found.

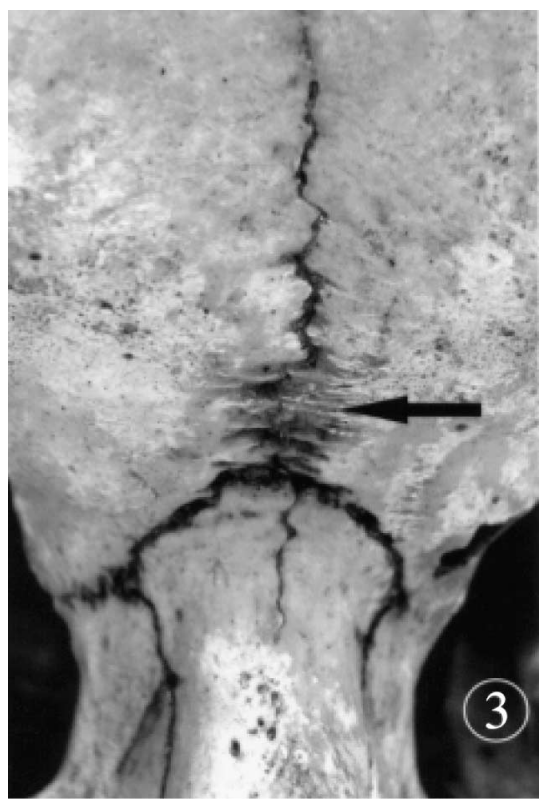

Fig. 3. Interdigitations of fine bridges above the nasion (arrow).

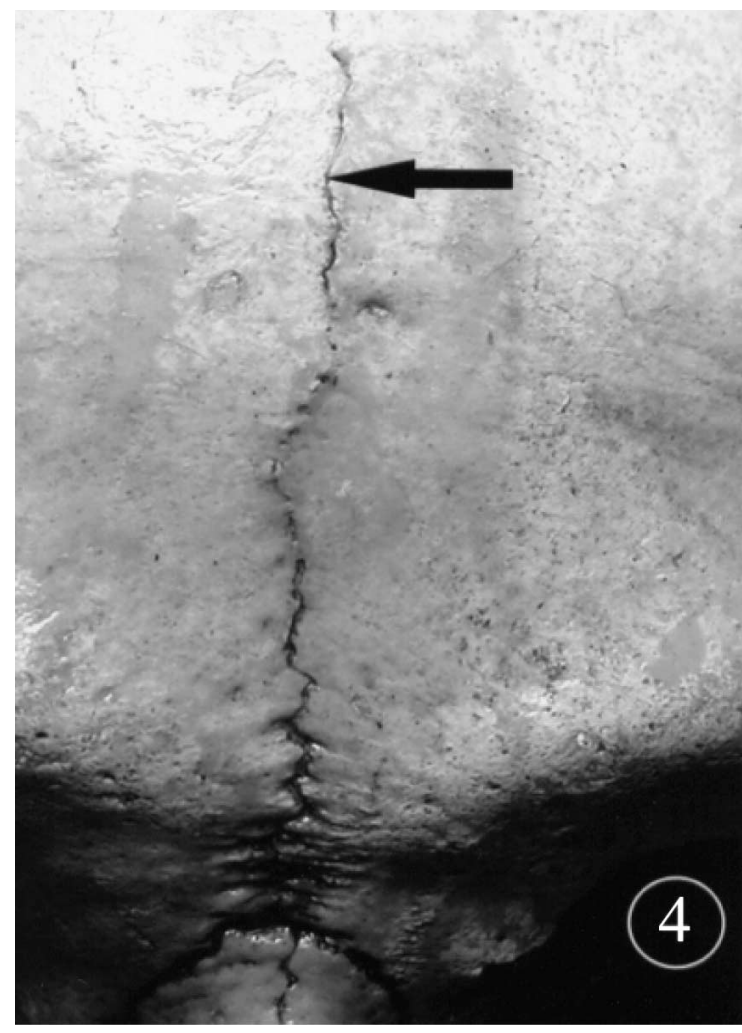

Fig. 4. Rectilinear region of the complete metopic suture near the ophrion (arrow).

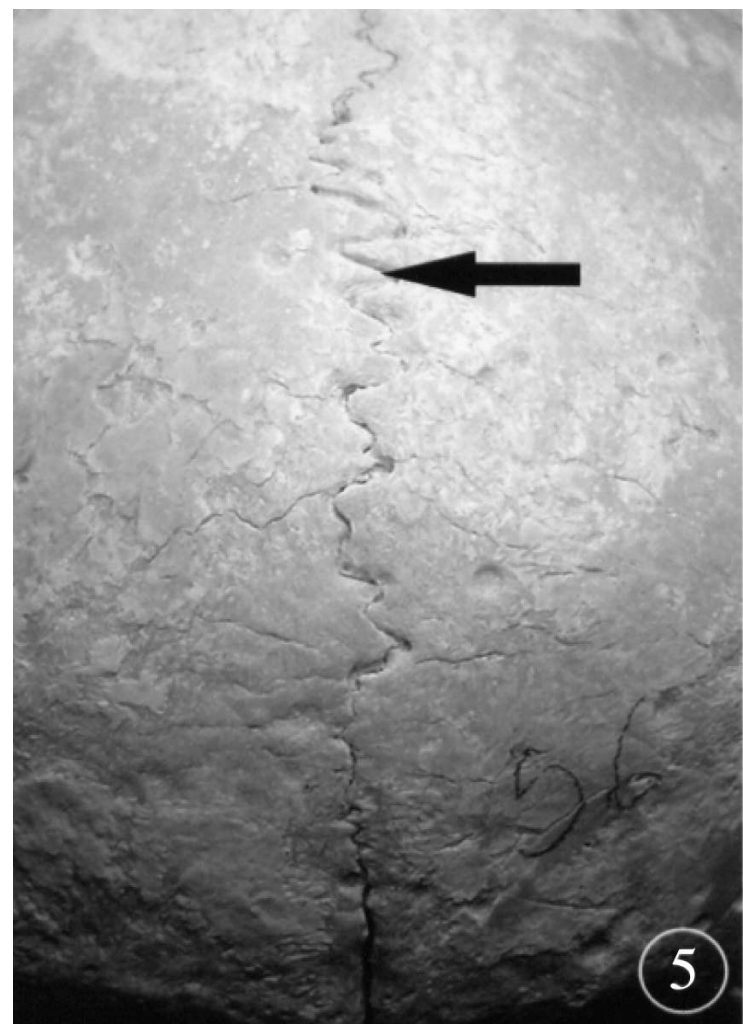

Fig. 5. Metopic suture showing "zig-zag" shape near the ophrion (arrow). 


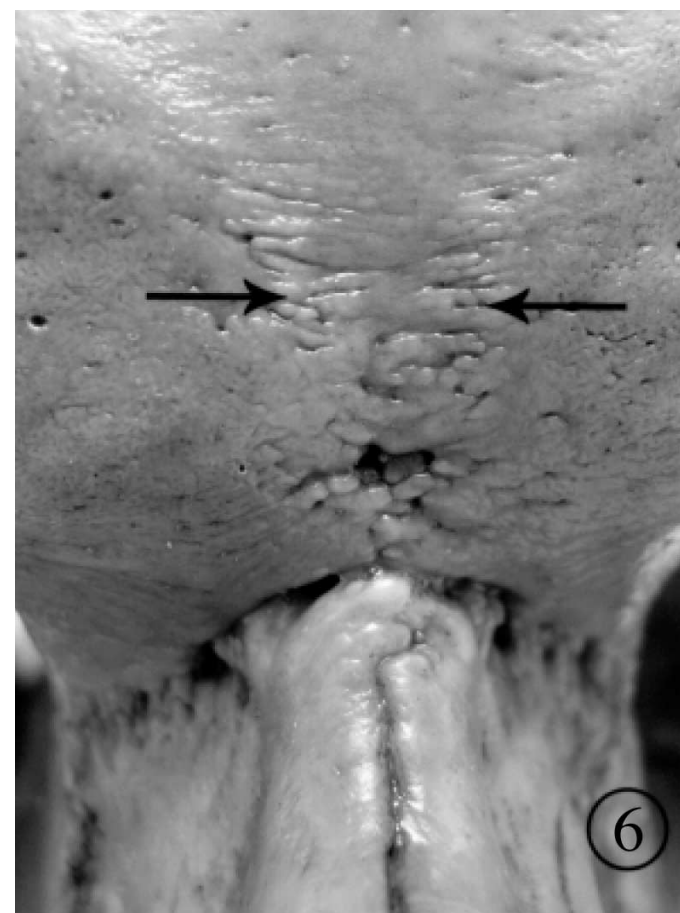

Fig. 6. V-shaped incomplete metopic suture (arrows).

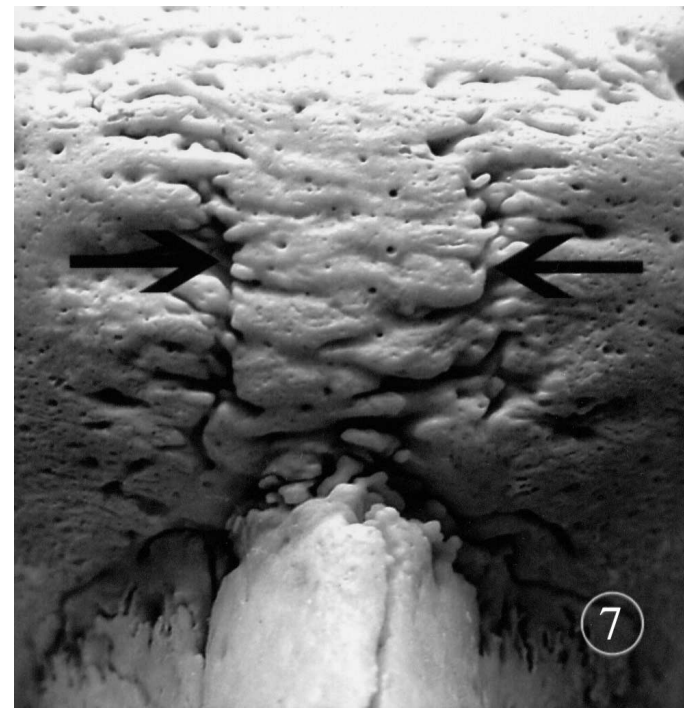

Fig. 7. Double-type incomplete metopic suture (arrows).

The mean length of the complete metopic suture was $12.92 \mathrm{~cm}$. On its portion immediately superior to the nasion it was linear and interdigitated by fine and simple "zig-zag"type bridges with width ranging from four to five mm (Fig. 3 ). Anteriorly and posteriorly to the ophryon (meeting point between the facial median line and a transverse line through the narrower portion of the forehead) the suture was rectilinear (Fig. 4), with a zig-zag appearance increasing towards the bregma in a typical serrated suture (Fig. 5); in its final portion

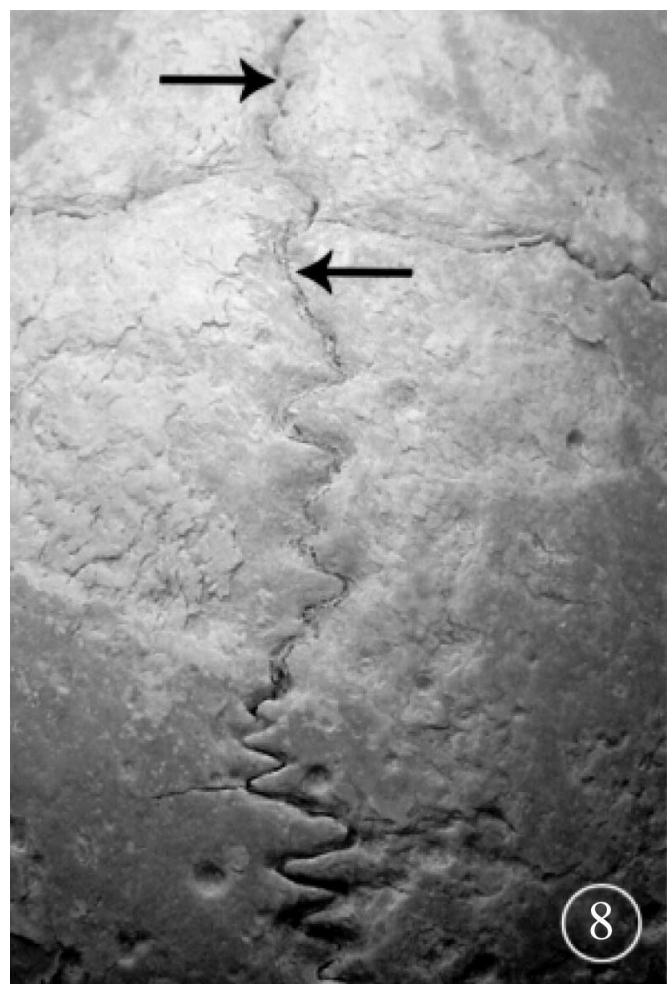

Fig. 8. Arrows showing the distance between the metopic and sagittal sutures.

it again becomes rectilinear in a more simple and direct manner. At the anterior end of the complete metopic suture there was not a continuity with the internasal suture in any of the cases. As for the posterior end, only one skull showed continuity with the sagittal suture.

The incomplete metopic sutures demonstrated shape variations (Table I). The most common shape was linear (Fig. 2) followed by the V-shape (Fig. 6). It was also found a type of incomplete metopic suture of double shape (Fig. 7) that was not found in the literature and that differed from the Vshaped because it had a double course all along its extension.

When the incidence of the different shapes of sutures was analyzed according to the anthropometric type of skull, it was verified that the incomplete sutures, in general, were found

$\begin{array}{lcccl}\text { Skull } & \text { Male } & \text { Female } & \text { Total } \\ \text { Linear } & 5(55,55 \%) & 11(78,58 \%) & 16(69,57 \%) \\ \text { "V" } & 2(22,22 \%) & 2(14,28 \%) & 4 & (17,39 \%) \\ \text { Double } & 2(22,22 \%) & 1(7,14 \%) & 3 & (13,04 \%) \\ \text { Total } & 9(100.0 \%) & 14(100 \%) & 23 & (100 \%)\end{array}$

Table I. Shape and incidence of the incomplete metopic suture in skulls from Southern Brazil according to sexual dimorphism. 
in larger numbers in brachicranics, while the double sutures were present only in the mesocranics (Table II). When the incidence of complete metopic suture was analyzed according to the anthropometric types it was observed that the mesocranic and dolichocranic represented the greatest incidence (40\%, $2 /$ $5)$, followed by the brachicranic $(20 \%, 1 / 5)$.

Table II. Incidence of the shapes of incomplete metopic sutures and the cranial index of skulls from Southern Brazil.

\section{DISCUSSION}

\begin{tabular}{lcllc} 
& Linear & \multicolumn{1}{c}{ "V" } & Double & Total \\
Brachycephalic & $10(62,5 \%)$ & $2(50 \%)$ & - & $12(52,2 \%)$ \\
Mesocephalic & $5(31,25 \%)$ & $1(25 \%)$ & $3(100 \%)$ & $9(39,1 \%)$ \\
Dolichocephalic & $1(6,25 \%)$ & $1(25 \%)$ & - & $2(8,7 \%)$ \\
Total & $16(100 \%)$ & $4(100 \%)$ & $3(100 \%)$ & $23(100 \%)$
\end{tabular}

The cranial sutures influence the growth of the whole skull and despite having been studied for decades there is no consensus about the correlation between cranial development and suture closure.

Baaten et al. (2003) showed that it is more likely to detect metopism directly on the organic piece, specially incomplete metopism when it is rudimentary and near the nasion, than in studies through radiographs, because X-ray studies can mistake the metopic suture for vertical fractures close to the central line, as well as the incomplete sutures can go unnoticed.

As for the complete suture this study detected five instances of complete metopism, $7.4 \%$ (female $14.28 \%$ and male $2.32 \%$ ). In a study carried out by del Sol et al. in 400 skulls of Brazilians, the incidence of metopism found was of $2.75 \%$ (female 2.96\% 4/135 and male 2.64\% 7/265). In the present study it can be noticed that the incidences of sex-independent metopism obtained were greater than those of del Sol et al. Even greater differences were observed when the sexes were analyzed separately, because the metopic suture was found in $14.28 \%$ of the female skulls analyzed (4/28) while del Sol et al. found $2.96 \%$. For the male sex, only one metopic suture was found $(2.32 \% 1 /$ 43 ) in opposition to the $2.64 \%$ observed by del Sol et al. Considering that both studies were made with Brazilian skulls it is believed that these data can be explained by two factors: first, the reduced size of the sample used here as compared to that of del Sol et al. and second, there is a difference between the geographic regions of Brazil. In their study, del Sol et al. obtained the skulls from the bone collection of the Paulista School of Medicine of the São Paulo University, Southeast of Brazil, and in the present work the skulls studied are from Southern Brazil. The Southeast region has a very miscellaneous population, characterized by internal migrations of Northeast Brazilians. The Southern region was colonized by Europeans (Camargo, 1998; Fausto, 2002), then Caucasians when longilineal types predominate. This hypothesis is reinforced by Bryce, who states that metopism is more frequent in populations of greater height.
The numbers obtained in this study were similar to those of Breathnach (1958) apud Baaten et al. with incidence of $7 \%$ in European skulls and those described by Czarnetzki (1972) apud del Sol et al., who found metopism in $11.2 \%$ of German female skulls. On the other hand, the smaller incidences were among blacks (Bryce, 1915 apud del Sol et al.), Nigerians (Ajmani et al.), and fell to $1.0 \%$ in Africans. (Breathnach, 1958 apud Baaten et al.).

Data greater than those of this work were obtained by other investigators, such as Aschley-Montagu (1937) apud del Sol et al. in Bolivians (20.24\%); Arensburg et al. (1977) in Bedouins (23\%); Comas et al. (1942) apud del Sol et al. in Alpine skulls $(63.2 \%)$ and in Genoese skulls (41.6\%).

As for the shape of the complete sutures, our results were similar to those of Agarwal et al. and Ajmani et al. The length of these sutures was greater than that described by del Sol et al.

For the incomplete sutures, the most common shape was linear, with $69.57 \%$ (16/23), close to the observed by del Sol et al. in Brazilian skulls, with $64.35 \%$ (74/400), but differed from those in other races; for instance, Ajmani et al. studied skulls from Nigerians and observed linear sutures in $24.27 \%$ (50/206) and the Hindu skulls studied by Agarwal et al. the incidence of this type of suture was of $23.12 \%$ (295/1276). The observation of the $\mathrm{V}$ shape was superior to those described in the literature, which in Hindus was $3.25 \%$ (Agarwal et al.), and in Nigerian skulls was of $0.49 \%$ (Ajmani et al.). As for the Brazilian skulls del Sol et al. when referring to the $\mathrm{V}$ shape, grouped it with other less common shapes of incomplete metopic sutures, obtaining a total of $6.95 \%$, so that a direct comparison with the present data was precluded.

Other shapes of incomplete metopic sutures were mentioned by Agarwal et al.; Ajmani et al. and del Sol et al., such as "n" type, "H" type and "U" type; these shapes were not found in this study. 
Bryce, studying the incidence of metopism, stated that there is no definite relation with brachicranic, in disagreement with the data of this study, because a high index $(52.71 \%)$ of brachicranics was obtained among the skulls with incomplete metopism and a small percentage of $20 \%$ (1/5) had complete metopism. In the literature there is no correlation with the anthropometric type of skull.

Agarwal et al. reported that the anterior and posterior ends of the complete metopic sutures did not meet thesagittal and internasal sutures (Fig. 8). This was confirmed in this work but in one out of five skulls studied, where the metopic suture directly contacted the sagittal suture.
In this work it is noted that wider studies are needed concerning the sub-populations of Brazil, enlarging the clinical fundamentals which in some areas is based on data of foreign populations. Deeper investigations will clarify the populational and regional differences within a country.

According to the international standards reported in the scientific literature it is concluded that the index of metopism found is within the global patterns and above those described for another Brazilian region. Obtaining more conclusive results demands the amplification of the number of skulls evaluated, as well as carrying out comparative studies between the different regions of Brazil.

CASTILlO, S. M. A.; ODA, Y. J. \& SANTÁNA, G. D. M. Metopismo en cráneos del Sur de Brasil. Int. J. Morphol., 24(1):61-66, 2006.

RESUMEN: La sutura metópica se encuentra entre las tuberosidades del hueso frontal, existiendo variaciones en relación a la fecha exacta de su cierre, ocurriendo entre el primero y el décimo año de vida, pudiendo persistir hasta la vida adulta (metopismo).

Se realizó un estudio en 71 cráneos secos, de individuos adultos, brasileños, de ambos sexos (43 masculinos y 28 femeninos), con edades variando entre 25-80 años de edad, pertenecientes a los osarios del Laboratorio de Anatomía Humana de la Universidad Paranaense - UNIPAR, Brasil.

La presencia de metopismo fue observada en el 7,04\% (05/71) de los cráneos estudiados, siendo 80\% (4/5) femeninos y sólo 20\% (1/5) masculinos. La sutura metópica incompleta fue encontrada en el 32,39\% de los casos (23/71), siendo más frecuente en el sexo femenino, 60,86\% (14/23) que en el sexo masculino 39,13\% de los casos (9/23). Las suturas metópicas presentaron variaciones en su morfología, siendo la forma más frecuente la del tipo linear, 69,56\% (16/23). Fueron observadas distintas suturas metópicas en los diversos tipos antropométricos de cráneo. Las suturas incompletas predominaron en los braquicráneos y las suturas metópicas completas tuvieron la misma incidencia en los mesocráneos de 40\% (2/5) y dolicocráneos de 40\% (2/5).

PALABRAS CLAVE: Anatomía Humana; Metopismo; Sutura metópica.

\section{REFERENCES}

Agarwal, S. K.; Melhotra, V. K. \& Tewari, S. P. Incidence of the metopic suture in adult Indian crania. Acta Anat., 105:469-74, 1979.

Ajmani, M. L.; Mittal, R. K. \& Jain, S. P. Incidence of the metopic suture in adult Nigerian Skulls. J. Anat., 137(1):177-83, 1983.

Arensburg, B.; Goldstein, M. S. \& Nathan, H. Metopism in Bedouin crania from the Negev of Israel. Z. Morphol. Anthropol., 68:2937, 1977.

Baaten, P. J. J.; Haddad, M.; Abi-nader, K.; Abi-ghosn, A.; Al-kutoubi, A. \& Jurjus, A.R. Incidence of metopism in the Lebanese population. Clin. Anat., 16:148-51, 2003.

Bryce, T. H. Observations on metopism. J. Anat., 51:153-66, 1917.

Camargo, J. B. Geografia Física, Humana e Econômica do Paraná. 2. ed. Paraná, Clichetec, 1998.

Del Sol, M.; Binvignat, O.; Bolini, P. D. A. \& Prates, J. C. Metopismo no individuo brasileiro. Rev. Paul. Med., 107(2):105-7, 1989.

Fausto, B. História do Brasil. 10. ed. São Paulo, Edusp, 2002.

Gray, H. Gray's Anatomia. 29. ed. São Paulo, Guanabara, 1988.

Hauser, G.; Mnazi,G.; Vienna, A. \& De Stefano, G. F. Size and shape of human cranial sutures - a new scoring method. Am. J. Anat. 190:231-44, 1991.
Keith, A. Human embryology and morphology. $6^{\text {th }}$ ed., London, Edward Arnold, 1948.

Madeira, M. C. Anatomia da face. São Paulo, Sarvier, 1995.

Manzanares, M. C.; Goret-nicaise, M. \& Dhen,A. Metopic sutural closere in the human skull. J. Anat., 161:203-15, 1988.

Moore, K. L. Anatomia Orientada Para a Clínica. 3. ed. Rio de Janeiro. Guanabara Koogan,1994.

Plese, J. P. P.; Sanematsu - JR. P. \& Rocha, D. L. Tratamento cirúrgico da criostenose da sutura metópica. J. Bras. Neurocirurg., 2(2): 49-52, 1990.

Watzek, G.; Grundschober, F.; Plenk, H. \& Eschberger, J. Experimental investigations into the clinical significance of bone growth at viscerocranial sutures. J. Maxillofacial Surgery., 10:61-76, 1982.

Correspondence to:

Prof. Marco Antonio Sant'Ana Castilfo

Laboratório de Anatomia Humana

Universidade Paranaense

Praça Mascarenhas de Moraes, $s / n$

CEP 87502210

Umuarama - PR

BRASIL

Email:castilfomar@terra.com.6r

Received : 07-11-2005

Accepted: 12-01-2006 